\title{
15. PRELIMINARY PETROLOGY OF LEG 34 BASALTS FROM THE NAZCA PLATE ${ }^{1}$
}

\author{
W. Ian Ridley and Joanna Ajdukiewicz, Lamont-Doherty \\ Geological Observatory of Columbia University, Palisades, New York
}

\section{INTRODUCTION}

Leg 34 of the Deep Sea Drilling Project cored basaltic basement at three locations within the Nazca plate. Site 319 within the Bauer Deep lies westward of the extinct Galapagos Rise and eastward of the presently active East Pacific Rise. Estimates of basement age are about 15 m.y. (Hart et al., 1974). Sites 320 and 321 lie between the Galapagos Rise and Peru-Chile Trench; Site 320 north and Site 321 south of the Mendaña Fracture Zone. Basement ages at both sites are estimated at 40-45 m.y.

Basement samples have been analyzed from Holes 319, 319A, and 320B, and Site 321. Data are reported for $\mathrm{Ti}, \mathrm{Zr}, \mathrm{Y}, \mathrm{Sr}, \mathrm{Rb}$, together with petrographic and phase chemistry data for samples taken at intervals down each core. Distribution of analyzed samples is shown in Table 1, and a crude estimate of the relationship of samples to proposed cooling units is shown in Figure 1. Petrographic descriptions of analyzed samples are given in Table 2.

TABLE 1

Distribution of Analyzed Samples

\begin{tabular}{|c|c|c|c|c|}
\hline $\begin{array}{l}\text { Sample } \\
\text { No. }\end{array}$ & Hole & Core & Section & $\begin{array}{c}\text { Depth Within Section } \\
(\mathrm{cm})\end{array}$ \\
\hline 1 & 319 & 13 & 1 & $77-80 \quad$ PTS $\left.^{\mathrm{a}} 75-78\right)$ \\
\hline 2 & $319 \mathrm{~A}$ & 1 & 1 & $48-51$ \\
\hline 3 & $319 \mathrm{~A}$ & 2 & 1 & $111-114$ \\
\hline 4 & $319 \mathrm{~A}$ & 3 & 1 & $78-81$ \\
\hline 5 & $319 \mathrm{~A}$ & 3 & 5 & $75-78$ \\
\hline 6 & 319A & 5 & 1 & $20-22$ \\
\hline 7 & $319 \mathrm{~A}$ & 6 & 1 & $93-98$ \\
\hline 8 & 319A & 7 & 1 & $121-124$ \\
\hline 9 & $320 \mathrm{~B}$ & 3 & 1 & $54-57$ \\
\hline 10 & $320 \mathrm{~B}$ & bit & & \\
\hline 11 & 321 & 14 & 1 & 42-45 (PTS 52-55) \\
\hline 12 & 321 & 14 & 2 & $9-12$ \\
\hline 13 & 321 & 14 & 3 & $4-7$ \\
\hline 14 & 321 & 14 & 4 & $7-10$ \\
\hline
\end{tabular}

${ }^{\text {aPTS }}=$ depth at which polished thin sections were taken when different from powdered samples.

\section{CHEMISTRY}

Data for $\mathrm{Ti}, \mathrm{Zr}, \mathrm{Y}, \mathrm{Sr}$, and $\mathrm{Rb}$ are shown in Table 3. $\mathrm{Ti}, \mathrm{Zr}$, and $\mathrm{Y}$ are relatively unaffected by subsolidus alteration (Pearce and Cann, 1971) and probably represent initial magmatic concentrations (Figure 2). Since

\footnotetext{
'Contribution No. 2205 of Lamont-Doherty Geological Observatory.
}

the basalts studied here generally show only minor alteration, $\mathrm{Rb}$ and $\mathrm{Sr}$ values may also be initial values. There is a close coherence between $\mathrm{Ti}$ and $\mathrm{Zr}$ and a weaker correlation between $\mathrm{Zr}$ and $\mathrm{Y}$. Ti/ $\mathrm{Zr}$ ratios remain fairly constant between 120 and 150; however, individual holes can be recognized on the basis of their trace element abundances. Site 321 has higher $\mathrm{Ti}, \mathrm{Zr}$, slightly higher $\mathrm{Y}$, and lower $\mathrm{Sr}$ compared to other holes.

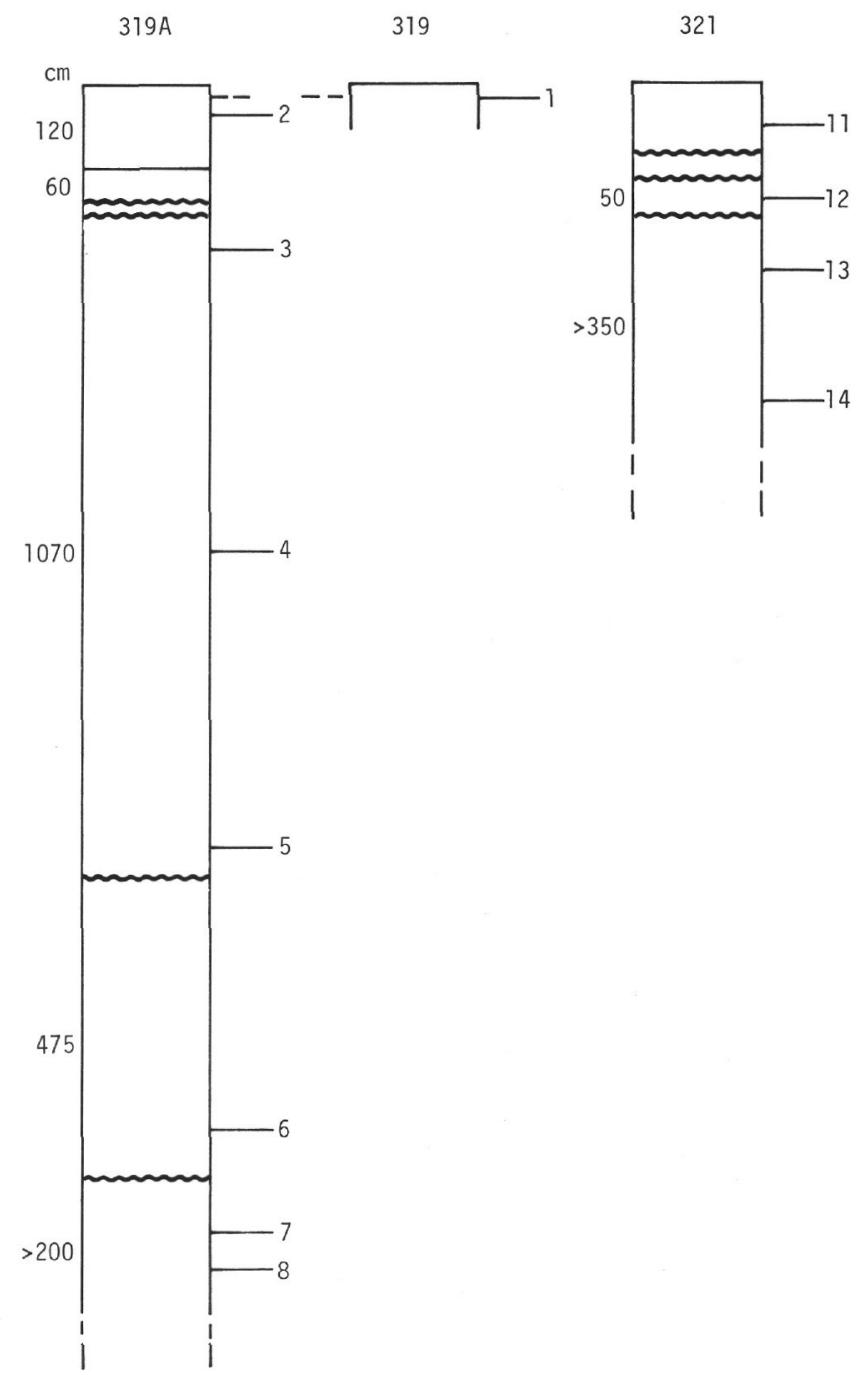

Figure 1. Location of analyzed samples relative to surmised cooling units (irregular lines) as described in core log. At Hole $319 \mathrm{~A}$ a tentative flow boundary has been drawn (straight line). Thickness of units are approximate accumulate thicknesses of recovered basalt, spacers, and voids. 
Hole 319 and the topmost sample from Hole 319A are relatively depleted in $\mathrm{Ti}, \mathrm{Zr}$, and $\mathrm{Y}$. In Figure 1 these samples are compared to distinct basalt types characterized by Pearce and Cann (1971). Only samples from Hole 320B fall in the range of typical abyssal tholeiites. A sample from Hole 319 and the topmost sample from Hole 319A are similar to abyssal tholeiites, but are slightly depleted in Zr. Basalts from Hole 319A and Site 321 are enriched in $\mathrm{Ti}, \mathrm{Zr}$ (and $\mathrm{Y}$ ) relative to abyssal tholeiites, and are clearly of a more alkalic nature, particularly samples from Site 321 .

TABLE 2

Brief Petrographic Description of Analyzed Samples

\begin{tabular}{ccl}
$\begin{array}{c}\text { Sample } \\
\text { No. }\end{array}$ & Hole & \multicolumn{1}{c}{ Description } \\
\hline 1 & 319 & $\begin{array}{l}\text { Very fine grained, aphyric; acicular plagioclase } \\
\text { and pyroxene, intergranular titanomagnetite and } \\
\text { rare ilmenite laths }\end{array}$ \\
2 & $319 \mathrm{~A}$ & $\begin{array}{l}\text { Medium grained, occasional plagioclase micro- } \\
\text { phenocrysts; intimately intergrown rosettes of } \\
\text { plagioclase and pyroxene; intergranular titano- } \\
\text { magnetite; Secondary iddingsite after anhedral } \\
\text { olivine }\end{array}$
\end{tabular}

$3 \quad$ 319A Fine grained with occasional plagioclase phenocrysts, showing strong optical zoning; groundmass texture similar to Sample No. 2; Chlorite fills interstitial areas and lines vesicles

$4 \quad 319$ A Essentially similar to Sample No. 3, but coarser grained, except for the lack of vesicles; yellowishbrown smectite replacing interstitial glass?

5 319A Medium grained; phenocrysts of zoned, anhedral plagioclase and rarer pseudomorphs after olivine; brown, interstitial smectite

6 319A Medium grained, massive, with occasional large plagioclase phenocrysts; interstitial yellowbrown smectite extensive; equigranular groundmass of lathy plagioclase, anhedral pyroxene, and intergranular titanomagnetite

7 319A Very fine grained, occasional plagioclase phenocrysts, and greenish-yellow smectite pseudomorphing olivine; acicular groundmass plagioclase and pyroxene; no opaques

$8 \quad 319$ A Essentially similar to Sample No. 7

$9320 \mathrm{~B}$ Very fine grained; common phenocrysts of zoned plagioclase; no visible opaques; Common iron oxide staining

10320 B Similar to Sample No. 9, except for a few irregular vesicles partly filled with yellow smectite

$11321 \quad$ Fine grained, rare plagioclase phenocrysts and very rare microphenocrysts of pyroxene; equigranular groundmass and interstitial dark brown glass; occasional irregular veins of iron sulphide

12321 Fine grained, abundant vesicles filled with calcite; otherwise similar to Sample No. 11

13,14 321 Fine grained, vesicles filled with calcite and brown smectite; abundant interstitial titanomagnetite and rarer ilmenite laths; intimately intergrown acicular plagioclase and pyroxene
TABLE 3

Minor and Trace Element Abundances ${ }^{\mathrm{a}}$

\begin{tabular}{cccccc}
\hline $\begin{array}{c}\text { Sample } \\
\text { No. }\end{array}$ & $\begin{array}{c}\mathrm{Ti} \\
(\%)\end{array}$ & $\begin{array}{c}\mathrm{Zr} \\
(\mathrm{ppm})\end{array}$ & $\begin{array}{c}\mathrm{Y} \\
(\mathrm{ppm})\end{array}$ & $\begin{array}{c}\mathrm{Sr} \\
(\mathrm{ppm})\end{array}$ & $\begin{array}{c}\mathrm{Rb} \\
(\mathrm{ppm})\end{array}$ \\
\hline Hole 319 & & & & & \\
1 & 0.90 & 60 & 31 & 120 & 4 \\
Hole 319A & & & & & \\
2 & 0.85 & 60 & 29 & 100 & $<1$ \\
3 & 1.52 & 110 & 45 & 128 & 11 \\
4 & 1.60 & 113 & 42 & 128 & $<1$ \\
5 & 1.52 & 110 & 42 & 113 & 2 \\
6 & 1.40 & 112 & 40 & 136 & 7 \\
7 & 1.32 & 113 & 43 & 120 & 9 \\
8 & 1.32 & 115 & 40 & 112 & $<1$ \\
& & & & & \\
Hole 320B & & & & & \\
9 & 0.99 & 96 & 38 & 132 & 4 \\
10 & 1.28 & 98 & 46 & 145 & 2 \\
& & & & & \\
Site 321 & & & & & \\
11 & 1.90 & 150 & 53 & 100 & 4 \\
12 & 1.64 & 124 & 53 & 102 & 2 \\
13 & 1.93 & 154 & 48 & 97 & 4 \\
14 & 1.73 & 113 & 48 & 95 & 4 \\
W-1 & & 95 & 24 & 194 & 24 \\
\hline
\end{tabular}

a Data collected by X-ray fluorescence techniques, as described by Pearce and Cann (1971).

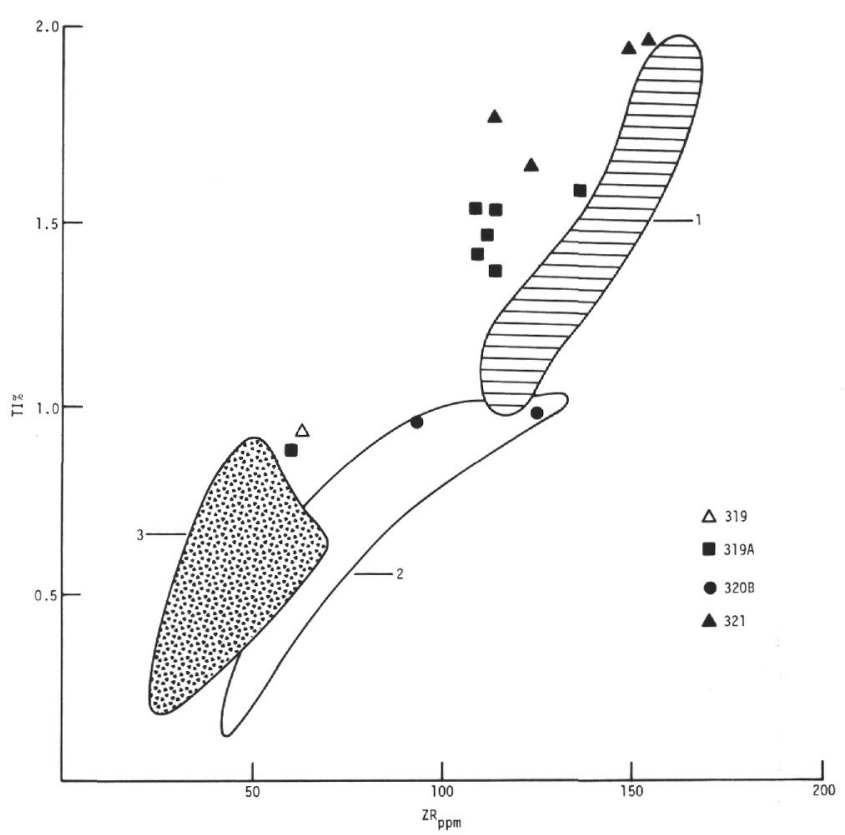

Figure 2. Plot of alteration-resistant pair Ti-Zr. Fields are Hawaiian tholeiites (1), abyssal tholeiites (2), Japanese tholeiites (3), derived from Pearce and Cann (1971).

\section{PHASE CHEMISTRY}

Microprobe data have been collected for pyroxenes, oxides, and plagioclases in representative basalts from each hole. Except for some plagioclases, all minerals are essentially fine-grained, groundmass grains. Titano- 
magnetite is ubiquitous, frequently associated with minor ilmenite. Subsolidus oxidation is rare, reflecting the overall freshness of these samples. Coexisting ilmenite-titanomagnetite pairs in Hole 319A and Site 321 give temperatures of $1050^{\circ}$ and $1080^{\circ} \mathrm{C}$, respectively (Table 4) using the curves of Buddington and Lindsley (1954). From the general aphyric textures, these values are assumed to be close to liquidus temperatures upon eruption.

Representative pyroxene analyses are shown in Table 5 and Figure 3. Pyroxene trends in individual crystals are shown in Figure 4. Two trends are evident, one involving iron enrichment at relatively constant calcium content, and a second representing little iron enrichment, but significant calcium depletion. The former probably represents the closest approach to equilibrium crystallization; the latter is a metastable, quench trend reflecting rapid cooling and crystallization. Overall, the concentrations of minor elements $\mathrm{TiO}_{2}$ and $\mathrm{Al}_{2} \mathrm{O}_{3}$ are high, compared, say, to Icelandic tholeiites (Carmichael, 1967) or Hawaiian tholeiites. With iron enrichment, $\mathrm{TiO}_{2}$ and $\mathrm{Al}_{2} \mathrm{O}_{3}$ decrease and $\mathrm{MnO}$ and $\mathrm{Na}_{2} \mathrm{O}$ increase slightly. No correlation exists between bulk $\mathrm{TiO}_{2}$ content and $\mathrm{TiO}_{2}$ in pyroxenes, i.e., Site 321 pyroxenes actually contain slightly lower $\mathrm{Al}_{2} \mathrm{O}_{3}$ and $\mathrm{TiO}_{2}$ compared to the other holes. $\mathrm{Al}_{2} \mathrm{O}_{3}$ contents, and consequently $\mathrm{TiO}_{2}$, in pyroxenes are controlled largely by silica activity (assuming $\mathrm{CaTiAl}_{2} \mathrm{O}_{6}$ is the major molecule; Carmichael et al., 1974). We might surmise that silica activity may be slightly higher in 321 basalts (more highly fractionated?) than the others, but all basalts have silica activities lying between Icelandic tholeiites and alkali basalts.

Data for plagioclases which point out that some grains are strongly zoned, are shown in Figure 5. Enrichment in the orthoclase molecule is noticeable but of minor significance, reflecting the overall low potash contents of the bulk systems. Although more precise data are required, it would appear that plagioclases in Hole 319 have lower orthoclase contents than in other samples. This may provide a good correlation with bulk $\mathrm{K}$ content (Ridley et al., 1974) and be useful in recognizing either different degrees of alkalinity in fresh basalts or secondary potash enrichment. Generally, increasing orthoclase is accompanied by increasing iron enrichment, although the trend is by no means well defined. This trend also corresponds to an increasing divergence from simple Si-Al stoichiometry, suggesting iron substitution as $\mathrm{Fe}_{2} \mathrm{O}_{3}$.

\section{CONCLUSIONS}

1. The chemical data suggest that at least two flows have been penetrated in Hole 319A. The topmost flow corresponds closely in trace element composition to basement penetrated in Hole 319, hence we might surmise both holes initially penetrated the same flow. Deeper penetration in Hole 319A located a more alkalic (or more fractionated) flow of several chemically similar flow units.

2. Although Hole 320B and Site 321 are relatively close together, the basement is chemically different. The alkalic or more fractionated flow at Site 321 may represent off-ridge volcanism and be a thin sill injected along the basalt-sediment interface. The higher $\mathrm{TiO}_{2}$ content compared to ridge tholeiites probably cannot be a consequence of small amounts of fractional crystallization from a ridge tholeiite parent magma. Site 321 magma was probably slightly different from ridge tholeiites at the source region either as a consequence of partial melting differences or source composition differences.

3. Only samples from Hole 319, the topmost flow at Hole 319A, and Hole 320B are typical ridge tholeiites. Their origin is somewhat equivocal for Site 319 samples since both the East Pacific Rise and the Galapagos Rise

TABLE 4

Analyses of Ilmenite and Titanomagnetite

\begin{tabular}{|c|c|c|c|c|c|c|c|c|}
\hline & \multicolumn{5}{|c|}{ Hole 319A } & \multicolumn{3}{|c|}{ Site 321} \\
\hline & \multicolumn{2}{|c|}{ Sample 4} & \multirow{2}{*}{$\begin{array}{l}\text { Sample } 6 \\
\text { Ilmenite }\end{array}$} & \multicolumn{2}{|c|}{ Sample 7} & \multicolumn{2}{|c|}{ Sample 13} & \multirow{2}{*}{$\begin{array}{l}\text { Sample } 14 \\
\text { Magnetite }\end{array}$} \\
\hline & Ilmenite & Magnetite & & Ilmenite & Magnetite & Ilmenite & Magnetite & \\
\hline $\mathrm{TiO}_{2}$ & 48.81 & 22.50 & 48.72 & 47.23 & 22.51 & 47.35 & 23.60 & 22.38 \\
\hline $\mathrm{Al}_{2} \mathrm{O}_{3}$ & 0.12 & 3.05 & 0.18 & 0.14 & 1.71 & 0.33 & 1.79 & 2.44 \\
\hline $\mathrm{Cr}_{2} \mathrm{O}_{3}$ & 0.03 & 0.05 & 0.02 & 0.02 & 0.05 & 0.01 & 0.05 & 0.08 \\
\hline $\mathrm{FeO}$ & 44.34 & 69.13 & 46.03 & 46.54 & 68.80 & 47.66 & 70.23 & 69.44 \\
\hline $\mathrm{MnO}$ & 0.57 & 0.57 & 0.99 & 0.65 & 0.60 & 0.63 & 0.57 & 0.55 \\
\hline $\mathrm{MgO}$ & 0.65 & 0.71 & 0.47 & 0.63 & 0.56 & 0.62 & 0.72 & 0.42 \\
\hline $\mathrm{Fe}_{2} \mathrm{O}_{3}$ & 3.04 & 22.08 & 5.96 & 7.91 & 21.12 & 9.56 & 20.96 & 22.72 \\
\hline $\mathrm{FeO}$ & 42.76 & 50.40 & 42.84 & 41.47 & 49.96 & 41.47 & 51.76 & 50.50 \\
\hline Total & 95.99 & 99.36 & 99.18 & & 97.07 & 99.97 & 99.43 & 99.40 \\
\hline$\%$ Ulv & \multirow{4}{*}{3.1} & 67.1 & \multirow{4}{*}{6.0} & & 68.0 & \multirow{4}{*}{\multicolumn{2}{|c|}{9.2}} & 68.0 \\
\hline$\% \mathrm{Ilm}$ & & & & 7.8 & & & & \\
\hline $\mathrm{T}^{\circ} \mathrm{C}$ & & & & & 50 & & & \\
\hline $\mathrm{fO}_{2}$ & & & & $10^{-}$ & 0.2 & & & \\
\hline
\end{tabular}

Note: Low totals reflect small grain size of opaque phases. 
TABLE 5

Analyses of Pyroxenes

\begin{tabular}{|c|c|c|c|c|c|c|c|c|c|c|c|c|c|}
\hline & \multicolumn{2}{|c|}{ Hole 319} & \multicolumn{11}{|c|}{ Hole 319A } \\
\hline & \multicolumn{2}{|c|}{ No. 1} & \multicolumn{3}{|c|}{ No. 2} & \multicolumn{2}{|c|}{ No. 3} & \multicolumn{3}{|c|}{ No. 4} & \multicolumn{3}{|c|}{ No. 5} \\
\hline & Core & Rim & Core & Rim & $\begin{array}{c}\text { Mesostasis } \\
\text { Grain }\end{array}$ & Core & Rim & Core & Interm. & Rim & Core & Interm. & Rim \\
\hline $\mathrm{SiO}_{2}$ & 50.73 & 50.19 & 49.64 & 49.59 & 47.26 & 49.58 & 49.83 & 49.83 & 50.53 & 50.15 & 49.94 & 50.68 & 49.39 \\
\hline $\mathrm{TiO}_{2}$ & 1.25 & 1.57 & 0.94 & 1.12 & 1.37 & 1.86 & 1.24 & 1.73 & 1.64 & 0.36 & 1.60 & 1.45 & 1.54 \\
\hline $\mathrm{Al}_{2} \mathrm{O}_{3}$ & 3.39 & 3.36 & 3.19 & 3.54 & 1.81 & 3.79 & 2.30 & 2.62 & 2.17 & 0.42 & 4.36 & 3.45 & 2.73 \\
\hline $\mathrm{FeO}$ & 10.20 & 14.42 & 8.14 & 7.16 & 20.54 & 10.97 & 14.28 & 14.81 & 16.21 & 25.50 & 7.86 & 9.89 & 13.76 \\
\hline $\mathrm{MnO}$ & 0.29 & 0.38 & 0.23 & 0.18 & 0.56 & 0.28 & 0.35 & 0.43 & 0.44 & 0.74 & 0.22 & 0.29 & 0.29 \\
\hline $\mathrm{MgO}$ & 15.50 & 13.61 & 16.04 & 15.96 & 11.55 & 14.40 & 15.00 & 13.27 & 12.11 & 5.95 & 15.89 & 14.76 & 12.88 \\
\hline $\mathrm{CaO}$ & 18.20 & 17.11 & 19.76 & 20.31 & 14.66 & 18.38 & 15.22 & 17.63 & 18.31 & 14.04 & 17.97 & 18.61 & 17.28 \\
\hline $\mathrm{Na}_{2} \mathrm{O}$ & 0.29 & 0.37 & 0.28 & 0.26 & 0.24 & 0.35 & 0.30 & 0.33 & 0.32 & 1.77 & 0.86 & 0.89 & 1.12 \\
\hline Total & 99.85 & 101.01 & 98.22 & 98.12 & 97.99 & 99.61 & 98.52 & 100.65 & 101.73 & 98.93 & 98.70 & 100.02 & 98.99 \\
\hline
\end{tabular}

\begin{tabular}{|c|c|c|c|c|c|c|c|c|c|c|c|c|}
\hline & \multicolumn{6}{|c|}{ Hole 319A } & \multirow{2}{*}{\multicolumn{4}{|c|}{$\begin{array}{c}\text { Hole } 320 \\
\text { No. } 10\end{array}$}} & \multirow{2}{*}{\multicolumn{2}{|c|}{$\begin{array}{c}\text { Site } 321 \\
\text { No. } 11\end{array}$}} \\
\hline & \multicolumn{2}{|c|}{ No. 6} & \multicolumn{2}{|c|}{ No. 7} & \multicolumn{2}{|c|}{ No. 8} & & & & & & \\
\hline & $\begin{array}{l}\text { Small } \\
\text { Grain }\end{array}$ & $\begin{array}{l}\text { Small } \\
\text { Grain }\end{array}$ & Core & $\operatorname{Rim}$ & Core & Rim & $\begin{array}{l}\text { Small } \\
\text { Grain }\end{array}$ & $\begin{array}{l}\text { Small } \\
\text { Grain }\end{array}$ & Core & Rim & Core & $\operatorname{Rim}$ \\
\hline $\mathrm{SiO}_{2}$ & 48.64 & 48.05 & 52.58 & 50.25 & 47.53 & 48.70 & 50.76 & 48.11 & 50.18 & 51.38 & 52.22 & 51.63 \\
\hline $\mathrm{TiO}_{2}$ & 1.88 & 1.90 & 0.83 & 1.33 & 2.35 & 0.85 & 1.31 & 2.34 & 1.64 & 0.73 & 0.77 & 1.05 \\
\hline $\mathrm{Al}_{2} \mathrm{O}_{3}$ & 4.31 & 3.47 & 1.95 & 1.37 & 4.72 & 1.14 & 5.21 & 3.16 & 2.54 & 1.11 & 2.71 & 1.63 \\
\hline $\mathrm{FeO}$ & 9.72 & 13.10 & 8.74 & 17.99 & 11.43 & 22.31 & 6.68 & 18.15 & 15.86 & 18.45 & 8.17 & 15.54 \\
\hline $\mathrm{MnO}$ & 0.26 & 0.34 & 0.28 & 0.54 & 0.28 & 0.63 & 0.18 & 0.43 & 0.44 & 0.52 & 0.25 & 0.40 \\
\hline $\mathrm{MgO}$ & 14.74 & 13.59 & 17.95 & 11.15 & 13.37 & 9.05 & 16.80 & 13.98 & 13.88 & 13.16 & 17.31 & 14.64 \\
\hline $\mathrm{CaO}$ & 20.11 & 18.67 & 16.98 & 16.64 & 18.39 & 14.78 & 19.25 & 12.81 & 15.78 & 15.84 & 19.33 & 16.14 \\
\hline $\mathrm{Na}_{2} \mathrm{O}$ & 0.34 & 0.34 & 0.78 & 1.04 & 1.17 & 0.80 & 0.76 & 0.86 & 0.19 & 0.18 & 0.24 & 0.23 \\
\hline Total & 100.00 & 99.46 & 100.09 & 100.31 & 99.24 & 98.26 & 100.95 & 99.84 & 100.51 & 101.37 & 101.00 & 101.26 \\
\hline
\end{tabular}

\begin{tabular}{|c|c|c|c|c|c|c|c|c|c|}
\hline & \multicolumn{9}{|c|}{ Site 321} \\
\hline & \multicolumn{4}{|c|}{ No. 12} & \multicolumn{2}{|c|}{ No. 13} & \multicolumn{3}{|c|}{ No. 14} \\
\hline & $\begin{array}{l}\text { Small } \\
\text { Grain }\end{array}$ & $\begin{array}{l}\text { Small } \\
\text { Grain }\end{array}$ & Core & $\operatorname{Rim}$ & Core & Rim & $\begin{array}{l}\text { Small } \\
\text { Grain }\end{array}$ & Core & Rim \\
\hline $\mathrm{SiO}_{2}$ & 49.06 & 50.27 & 50.20 & 49.26 & 51.34 & 50.24 & 50.50 & 50.68 & 49.54 \\
\hline $\mathrm{TiO}_{2}$ & 1.42 & 1.23 & 1.60 & 1.41 & 0.91 & 0.89 & 1.13 & 1.40 & 1.70 \\
\hline $\mathrm{Al}_{2} \mathrm{O}_{3}$ & 3.08 & 1.58 & 2.48 & 1.74 & 1.04 & 1.02 & 2.17 & 2.28 & 1.72 \\
\hline $\mathrm{FeO}$ & 12.75 & 16.98 & 14.29 & 17.66 & 17.48 & 19.04 & 8.79 & 11.49 & 15.84 \\
\hline $\mathrm{MnO}$ & 0.34 & 0.48 & 0.39 & 0.52 & 0.53 & 0.59 & 0.25 & 0.31 & 0.42 \\
\hline $\mathrm{MgO}$ & 15.87 & 13.15 & 12.12 & 9.82 & 14.04 & 11.56 & 15.35 & 14.71 & 12.20 \\
\hline $\mathrm{CaO}$ & 17.77 & 16.69 & 18.55 & 18.49 & 14.53 & 15.47 & 19.90 & 18.41 & 17.69 \\
\hline $\mathrm{Na}_{2} \mathrm{O}$ & 0.29 & 0.21 & 0.29 & 0.23 & 0.14 & 0.16 & 0.82 & 0.89 & 0.94 \\
\hline Total & 100.58 & 100.59 & 99.92 & 99.13 & 100.01 & 98.97 & 98.91 & 100.17 & 100.05 \\
\hline
\end{tabular}

were actively spreading at this time (Herron, 1972). The more evolved nature of the majority of the basalt cored at Hole 319A suggests this may also be the product of off-ridge volcanism. The freshness of basalt cored at Hole 320B and Site 321 seems inconsistent with an age of $\sim 40 \mathrm{~m} . \mathrm{y}$. deduced from the anomaly pattern. Here again we may be dealing with later, off-ridge volcanism which in the case of Hole 320B produced basalt similar to ridge tholeiite.

4. Magma erupted with few or no phenocrysts and cooled quickly. This resulted in some mineral zoning and preservation of metastable compositional trends.
Eruption temperatures were above $1050^{\circ} \mathrm{C}$ and $\mathrm{fO}_{2}$ about $10^{-10}$ bars.

\section{ACKNOWLEDGMENTS}

Ti data were obtained by M. Perfit. We are grateful to Stan Hart and the Deep Sea Drilling Project (NSF) for access to Leg 34 samples. This work was supported by National Science Foundation Grant GX 39231 (IDOE).

\section{REFERENCES}

Buddington, A.F. and Lindsley, D.H., 1964. Iron-titanium oxide minerals and synthetic equivalents) J. Petrol., v. 5, p. $310-357$. 


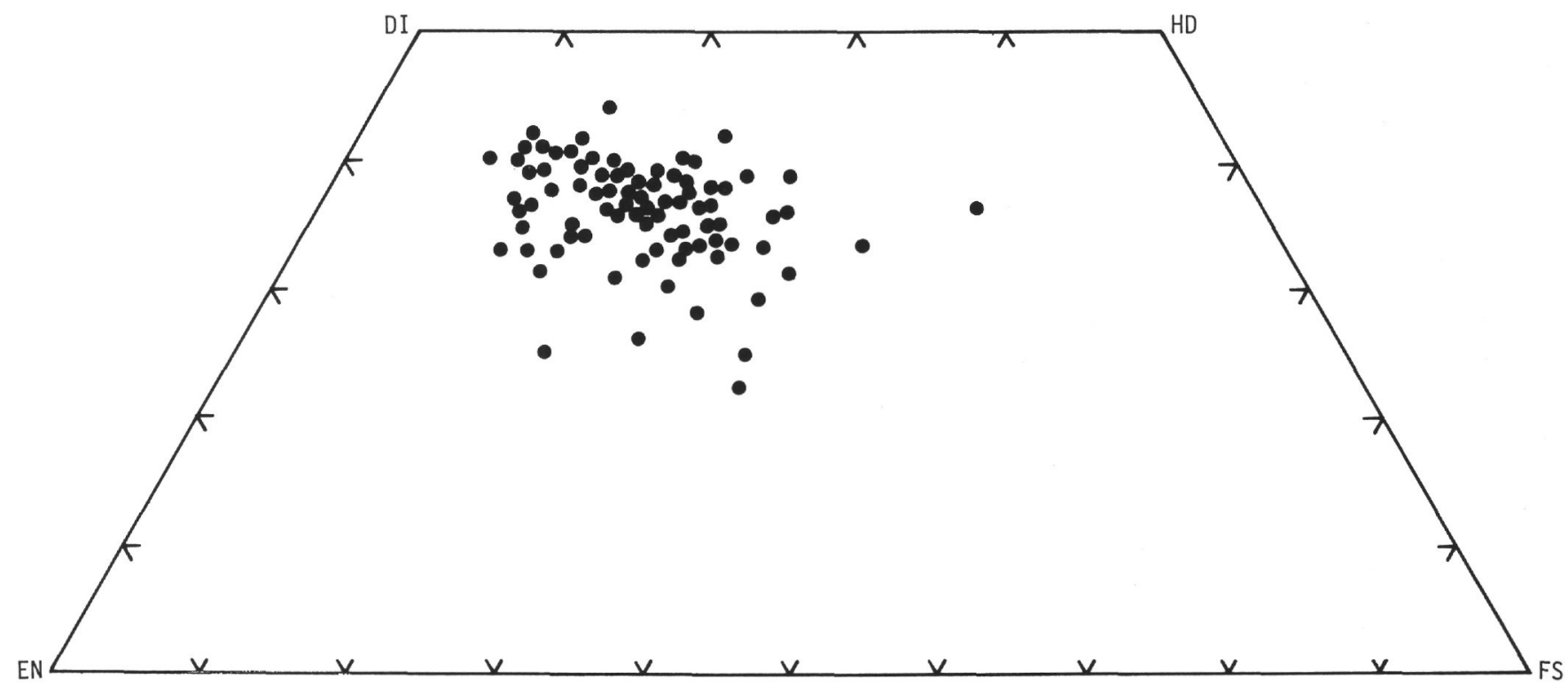

Figure 3. Composition of all pyroxenes in terms of enstatite (EN)-diopside (DI)-hedenbergite (HD)-ferrosilite (FS).

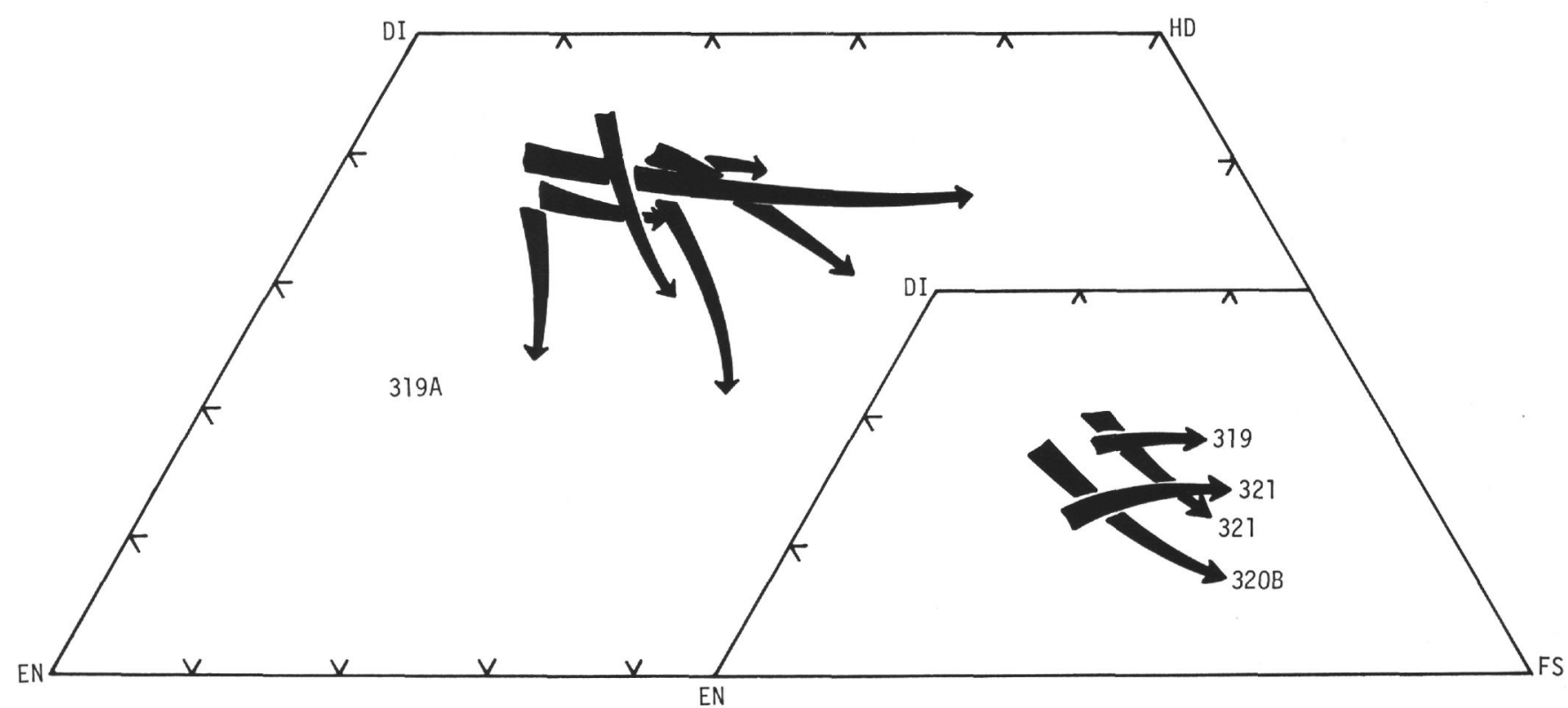

Figure 4. Composition trends in individual pyroxenes. Inset trends are for Holes 319, 320B, and Site 321.

Carmichael, I.S.E., 1967. The mineralogy of Thingmuli, a Tertiary volcano in eastern Iceland: Am. Mineralogist, v. 52, p. 1815-1841.

Carmichael, I.S.E., Turner, F.J., and Verhoogen, J., 1974. Igneous petrology: New York (McGraw-Hill).

Hart, S.R., et al., 1974. Oceanic basalts and the Nazca plate: Geotimes, v. 19, p. 20-24.
Herron, E.M., 1972. Sea-floor spreading and the Cenozoic history of the East-Central Pacific: Geol. Soc. Am. Bull., v. 83, p. 1671-1792.

Pearce, J.A. and Cann, J.R., 1971. Ophiolite origin investigated by discriminant analysis using $\mathrm{Ti}, \mathrm{Zr}$ and $\mathrm{Y}$ : Earth Planet. Sci. Lett., v. 12, p. 339-349.

Ridley, W.I., Rhodes, J.M., Reid, A.M., Jakes, P., Shih, C., and Bass, M.N., 1974. Basalts from Leg 6 of the Deep Sea Drilling Project: J. Petrol., v. 15, p. 140-159. 
W. I. RIDLEY, J. AJDUKIEWICZ
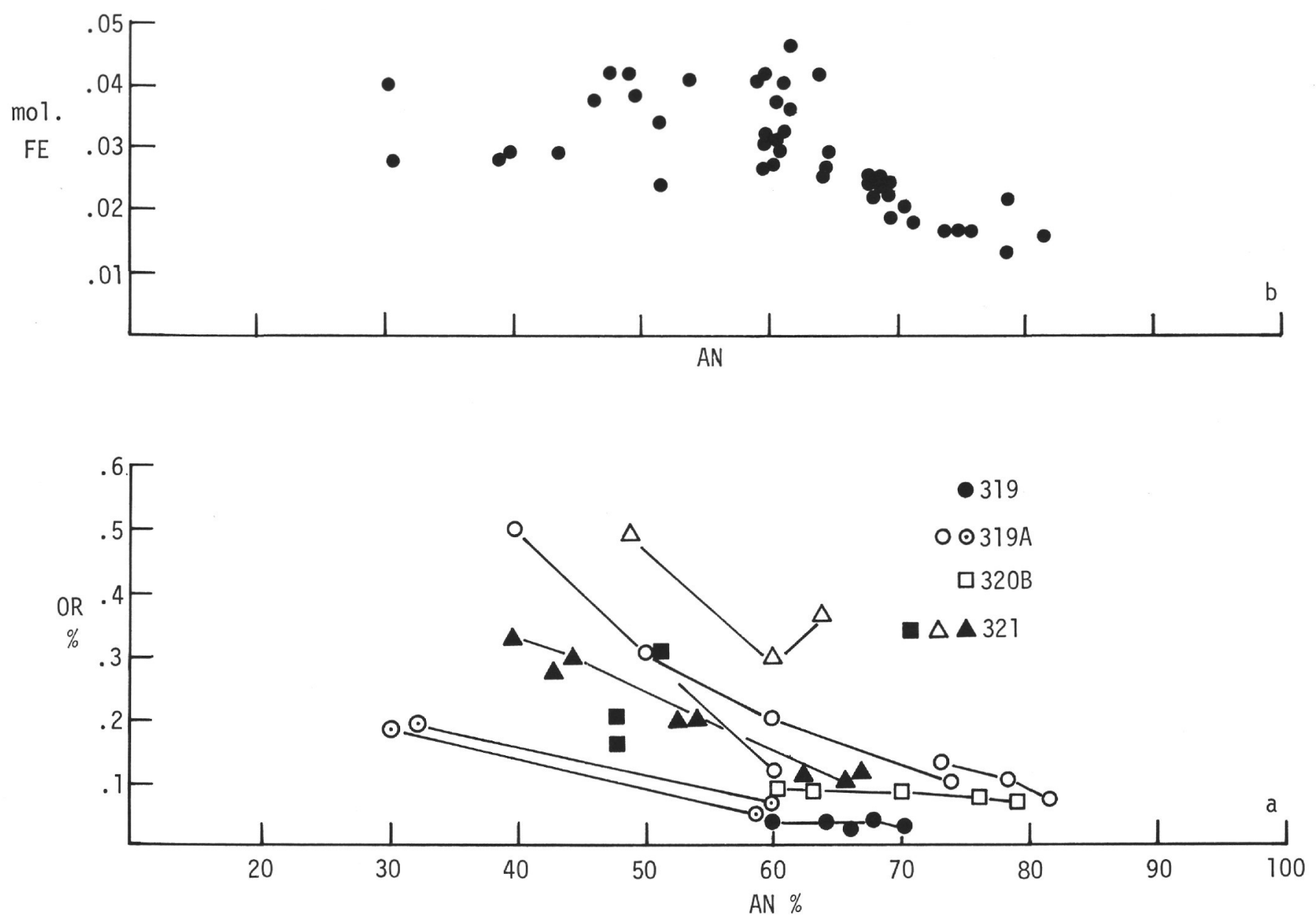

Figure 5. Compositional trends in plagioclases. (a) anorthite (AN) and orthoclase (OR) variations. Lines indicate zoning trends in individual grains. (b) Anorthite and molecular iron variations. 